\title{
Immobilization of the Candida rugosa lipase onto a Scirpus grossus L.f. fiber as biocatalyst for biodiesel synthesis via hydrolysis-esterification
}

\author{
Sireerat Charuchinda ${ }^{1,3,4_{\star}}$, Pichaya Kensingh ${ }^{1}$ and Warawut Chulalaksananukul ${ }^{2,3}$ \\ ${ }^{1}$ Center of Excellence in Textiles, Department of Materials Science, Faculty of Science, Chulalongkorn University, \\ Phyathai Road, Patumwan, Bangkok 10330, Thailand. \\ ${ }^{2}$ Department of Botany, Faculty of Science, Chulalongkorn University, Phyathai Road, Patumwan, \\ Bangkok 10330, Thailand. \\ ${ }^{3}$ Biofuel Production by Biocatalyst Research Unit, Chulalongkorn University, Phyathai Road, \\ Patumwan, Bangkok 10330, Thailand. \\ ${ }^{4}$ Center of Excellence on Petrochemical and Materials Technology, Chulalongkorn University, \\ Phyathai Road, Patumwan, Bangkok 10330, Thailand.
}

Accepted 10 October, 2013

\begin{abstract}
This study aimed to immobilize the Candida rugosa lipase (C. rugosa lipase) on ground Scirpus grossus L.f. fibers by glutaraldehyde-crosslinking to form a hydrolysis-esterification catalyst for biodiesel synthesis. The effects of different glutaraldehyde concentrations and solvent for 3aminopropyltriethoxysilane (3-APTES) activation of the fibers on the resultant immobilized lipase activity, protein loading, degree of immobilization and catalytic efficiency were investigated. The optimum condition found was to first activate the $S$. grossus L.f. fibers using $2 \%(w / v)$ of 3 -APTES in distilled water and subsequently crosslink with $0.2 \%(\mathrm{w} / \mathrm{v})$ glutaraldehyde prior to $C$. rugosa lipase immobilization at $\mathrm{pH}$ 7. The immobilized $C$. rugosa lipase was then evaluated as a biocatalyst for biodiesel synthesis via the hydrolysis-esterification of palm oil and bioethanol through monitoring the production of free fatty acids (FFAs) and fatty acid ethyl ester (FAEE, biodiesel). The reusability of immobilized lipase was also determined. The immobilized $C$. rugosa lipase yielded a higher hydrolysisesterification efficiency (that is, FFA and FAEE formation) than that of the free lipase with the immobilized form looking promising for FAEE biodiesel production. The $C$. rugosa lipase immobilized with $0.2 \%(\mathrm{w} / \mathrm{v})$ glutaraldehyde exhibited the highest reuse stability, retaining some hydrolysis and esterification activity for up to six uses, whereas crosslinking with higher $[0.5 \%$ or $0.8 \%(w / v)]$ glutaraldehyde levels resulted in a loss of both activities within four uses.
\end{abstract}

Key words: Immobilization, lipase, Scirpus grossus L.f. fiber, 3-aminopropyltriethoxysilane, glutaraldehyde, biodiesel.

\section{INTRODUCTION}

Currently, the limited petroleum-based oil reserves, the increase of oil price due to the decrease of crude oil production because of the political problem of the middleeast countries, and the environmental concerns from $\mathrm{CO}_{2}$ emission have urged many researchers to develop alternative renewable energy sources. Biodiesel is viewed as one of the new potential alternative renewable, non-toxic, biodegradable and clean energy sources for 
petroleum-based fuel replacement (Gerpen, 2005). It is claimed as a nonpolluting fuel because the burning of biodiesel does not contribute to global warming due to its large reduction of $\mathrm{CO}_{2}$ emission compare with petroleumbased oil. Although, biodiesel can be successfully produced by chemical catalysis, this is a high energy consumption process and the recovery of the biodiesel from the glycerol byproduct is difficult. Moreover, this process also produces large amounts (ca. 10\% of the volume of biodiesel produced) of non-environmentally friendly wastewater that is difficult to treat and also expensive. Recently, the use of lipase as biocatalyst instead of acid or alkali catalysts has attracted considerable attention because byproduct glycerol can be recovered easily and the purification of the biodiesel (fatty acid methyl esters, FAME) is simple to accomplish. In addition, this process is non-toxic, has a lower energy requirement, and also has biodegradable characteristics (Shimada et al., 1999; Nelson et al., 1996). However, the high cost of lipase makes enzymatic processes commercially unattractive. Therefore, immobilization of lipase has advantages over free lipase in terms of its reusability, its ease of removal from the reaction mixture and its adaptability to various engineering designs (Xie and $\mathrm{Ma}$, 2009). Nevertheless, the high cost of com-mercial immobilized lipase due in part to the requirement for expensive support materials, makes production of biodiesel by this approach more expensive than that produced by chemical catalysis and so it is not economically viable. Thus, cheaper supports such as clays, silica gels and glasses have been evaluated as alternative adsorbents to the expensive polymeric resins (Hung et al., 2003; Minovska et al., 2005; Lee et al., 2006; Sugunan et al., 2007).

Other attractive supports are plant fibers that are composed of cellulose because of their accessibility, cheapness, hydrophilic nature and the great number of hydroxyl groups on the surface that are capable of chemical reaction (Przybyt and Sugier, 1988). In addition, most of them possess a large number of pores, allowing the lipase to be immobilized onto the plant fibers through simple adsorption. Scirpus grossus L.f. or Cyperus papyrus L., is an abundant biomass cellulose fiber in Thailand. Due to its very low cost, lack of toxicity and its chemical reactivity that allows it to react with the enzyme easily, S. grossus L.f. fibers are viewed as a non-toxic, economic and environmental friendly support for lipase immobilization. Lipase immobilization onto $S$. grossus L.f. fibers by physical adsorption is simple but appears to be that they cannot maintain their active configuration and so lose catalytic activity with time for biodiesel production via transesterification. Lee et al. (2006) developed a suitable method for the immobilization of Rhizopus oryzae lipase on silica gel using glutaraldehyde as a crosslinking agent, reporting on the optimizing of each step of the immobilization procedures, such as the pretreatment of silica gel, silanization, crosslinking and glutaralde- dehyde modification.

Silanization on the silica gel surface using 3aminopropyltriethoxysilane (3-APTES) exhibited the highest resultant catalytic activity of the immobilized lipase. Furthermore, after 20 consecutive uses in a 30 min reaction with repeated washing between each reaction, some $80 \%$ of the enzyme activity of the immobilized lipase was still retained. Wang et al. (2008) reported that the immobilization of Candida rugosa lipase ( $C$. rugosa lipase) onto the dense surface of a polysulfone ultrafiltration membrane by filtration and then crosslinking with glutaraldehyde solution greatly improved the lifetime of the enzyme. The apparent reaction rate and stability of the immobilized lipase were greatly improved after crosslinking. Xie and Ma (2009) reported that immobilized lipase on $\mathrm{Fe}_{3} \mathrm{O}_{4}$ nanoparticles treated with 3-APTES was using as biocatalyst for biodiesel production via transesterification. The conversion of soybean oil to biodiesel fuels reached over $90 \%$ by the three-step addition of methanol when $60 \%$ immobilized lipase was employed. In addition, it could be used four times without significant decrease of activity. Thus, to reduce the hydrophilicity of $S$. grossus L.f. and enhance the stability and retain a high catalytic activity of the immobilized lipase, it is necessary to modify or activate the surface properties of cellulosic fibers enriched with hydroxyl groups using a silane coupling agent and subsequent crosslinking of the lipase to the support material using glutaraldehyde.

In this study, glutaraldehyde-crosslinking based immobilization of the $C$. rugosa lipase onto 3-APTES activated ground $S$. grossus L.f. fiber was investigated for its suitability for biodiesel synthesis. Protein loading, lipase activity and degree of immobilization of immobilized the $C$. rugosa lipase were subsequently determined. The catalytic activities of the immobilized $C$. rugosa lipase in a hydrolysis-esterification reaction using palm oil and bioethanol for FAEE biodiesel synthesis was also examined to ascertain its biocatalyst potential including the reusability of the immobilized $C$. rugosa lipase.

\section{MATERIALS AND METHODS}

C. rugosa lipase powder (EC 3.1.1.3) was purchased from SigmaAldrich (USA). Plant fibers of $S$. grossus L.f. from Nakhon Ratchasima Province (Thailand) were used as the support. They were dried and ground into fine powder using a Pulverizer model T15 before use. 3-APTES used for the activation of hydroxyl group of S. grossus L.f. and glutaraldehyde (50\% in water) used as a crosslinking agent, were purchased from Fluka (Switzerland). Palm oil was obtained from Morakot Industries (Thailand) and used as the substrate triglyceride. Bioethanol was kindly provided by the Petroleum Authority of Thailand.

\section{C. rugosa lipase immobilization}

The procedure for $C$. rugosa lipase immobilization was composed 


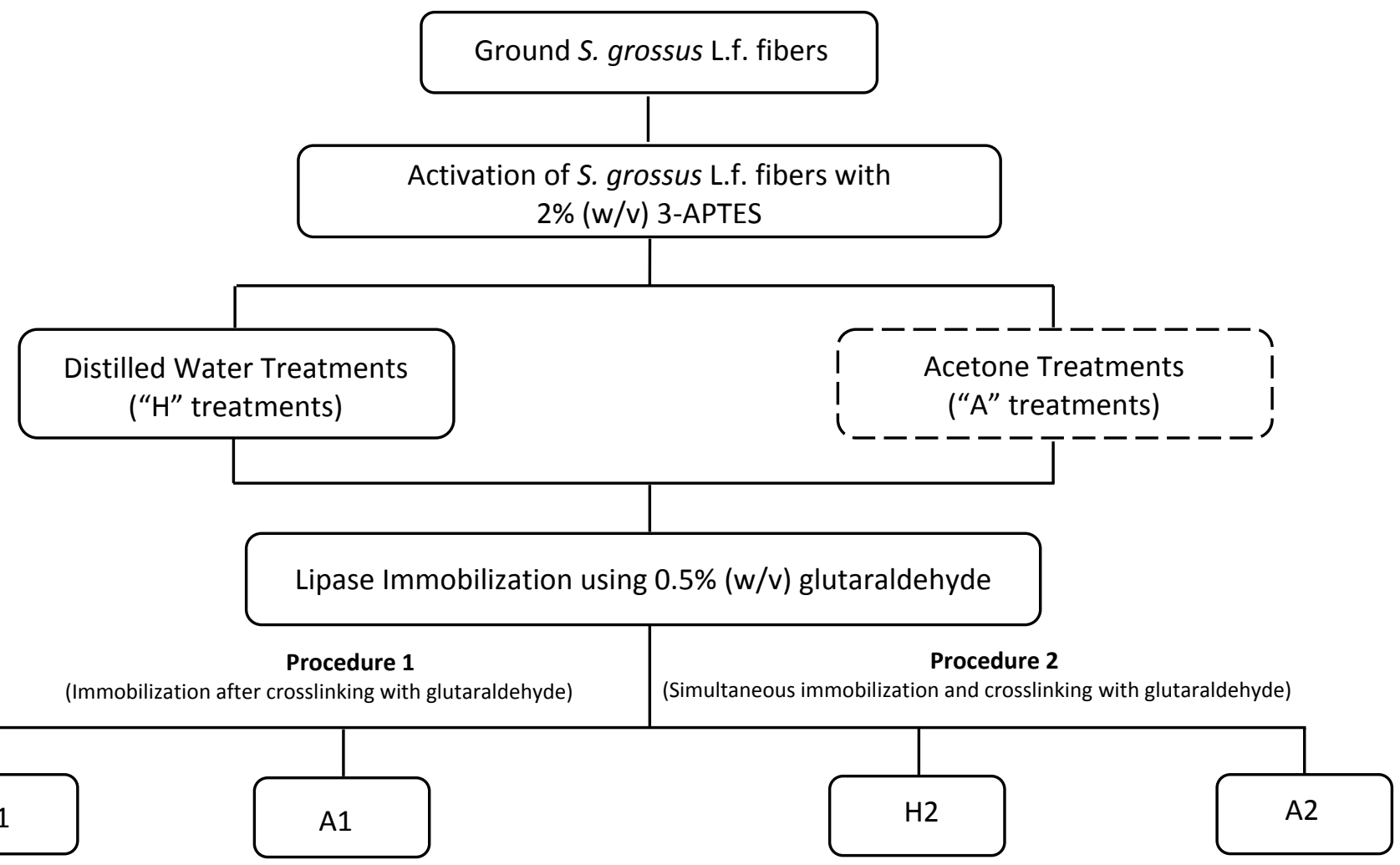

Figure 1. Flow diagram of $C$. rugosa lipase immobilization onto ground $S$. grossus L. f. fibers.

of two main steps. The first step was to activate the ground fiber using 3-APTES solution in either distilled water ( $\mathrm{H}$ treatment) or in acetone (A treatment). The second step was to immobilize the $C$. rugosa lipase before crosslinking with glutaraldehyde $(\mathrm{A} 1$ and $\mathrm{H} 1$ treatments) or to simultaneously immobilize and crosslink the lipase onto the fibers with glutaraldehyde ( $\mathrm{A} 2$ and $\mathrm{H} 2$ treatments), as detailed below. The flow diagram of the $C$. rugosa lipase immobilization is shown in Figure 1.

\section{Activation of S. grossus L.f. fibers with 3-APTES in distilled water (H treatments) or in acetone (A treatments)}

Five grams of ground S. grossus L.f. fibers was mixed with $100 \mathrm{ml}$ of $2 \%(w / v)$ of 3 -APTES solution in either distilled water or in acetone and stirred at $360 \mathrm{rpm}$ for $30 \mathrm{~min}$. The activated ground fiber was then washed with distilled water three times and left to dry at $80^{\circ} \mathrm{C}$ for $6 \mathrm{~h}$.

\section{Lipase immobilization using glutaraldehyde as a crosslinking agent}

Procedure 1 (immobilization after crosslinking): One gram of the $\mathrm{H}$ or $\mathrm{A}$ activated ground $\mathrm{S}$. grossus L.f. fibers crosslinked with $20 \mathrm{ml}$ of $0.5 \%(\mathrm{w} / \mathrm{v})$ glutaraldehyde in $0.05 \mathrm{M}$ phosphate buffer $(\mathrm{pH}$ 7). The reaction mixture was stirred at $360 \mathrm{rpm}$ for $1 \mathrm{~h}$ at room temperature and then washed with distilled water three times, vacuum filtered, left to dry and kept in a desiccator. Thereafter, 0.5 $\mathrm{g}$ of the crosslinked-ground fiber was mixed with $10 \mathrm{ml}$ of a 0.01 $\mathrm{g} / \mathrm{ml} \mathrm{C}$. rugosa lipase solution in $1 \mathrm{M}$ phosphate buffer $(\mathrm{pH} 7)$ and stirred at $360 \mathrm{rpm}$ for $12 \mathrm{~h}$ at room temperature. The immobilized lipase was then washed six times, each with $10 \mathrm{ml}$ of $0.05 \mathrm{M}$ phosphate buffer solution ( $\mathrm{pH} 7)$, vacuum filtered and left to dry in a desiccator for overnight prior to storage at $4^{\circ} \mathrm{C}$.

Procedure 2 (simultaneous immobilization and crosslinking): To $0.5 \mathrm{~g}$ of $\mathrm{A}$ or $\mathrm{H}$ treated ground, S. grossus L.f. fibers was mixed with $10 \mathrm{ml}$ of $0.01 \mathrm{~g} / \mathrm{ml} \mathrm{C}$. rugosa lipase solution in $1 \mathrm{M}$ phosphate buffer $(\mathrm{pH} \mathrm{7)}$, and $100 \mu \mathrm{l}$ of glutaraldehyde [at $0.2,0.5$ or $0.8 \%$ $(\mathrm{w} / \mathrm{v})$ ] was then added and stirred at $360 \mathrm{rpm}$ for $12 \mathrm{~h}$ at room temperature. The immobilized lipase was then washed six times, each with $10 \mathrm{ml}$ of $0.05 \mathrm{M}$ phosphate buffer $(\mathrm{pH} 7)$, vacuum filtered, dried and kept in a desiccator overnight and stored at $4^{\circ} \mathrm{C}$.

\section{Morphology of immobilized lipase}

Scanning Electron Microscopy (SEM), using a Jeol JSM-5800 LV electron microscope (Japan) under an accelerated voltage of 15 $\mathrm{KV}$, was performed at a magnification of $750 \mathrm{x}$ to examine the morphology of the ground $S$. grossus L.f. fibers and the adsorption of the $C$. rugosa lipase to the fiber support after immobilization.

\section{Determination of $C$. rugosa lipase activity}

The activity of the free and immobilized lipase was determined using $0.5 \%(\mathrm{w} / \mathrm{v})$ p-nitrophenyl palmitate ( $p$-NPP) in ethanol as the substrate. The increase in absorbance at $410 \mathrm{~nm}$ caused by the 

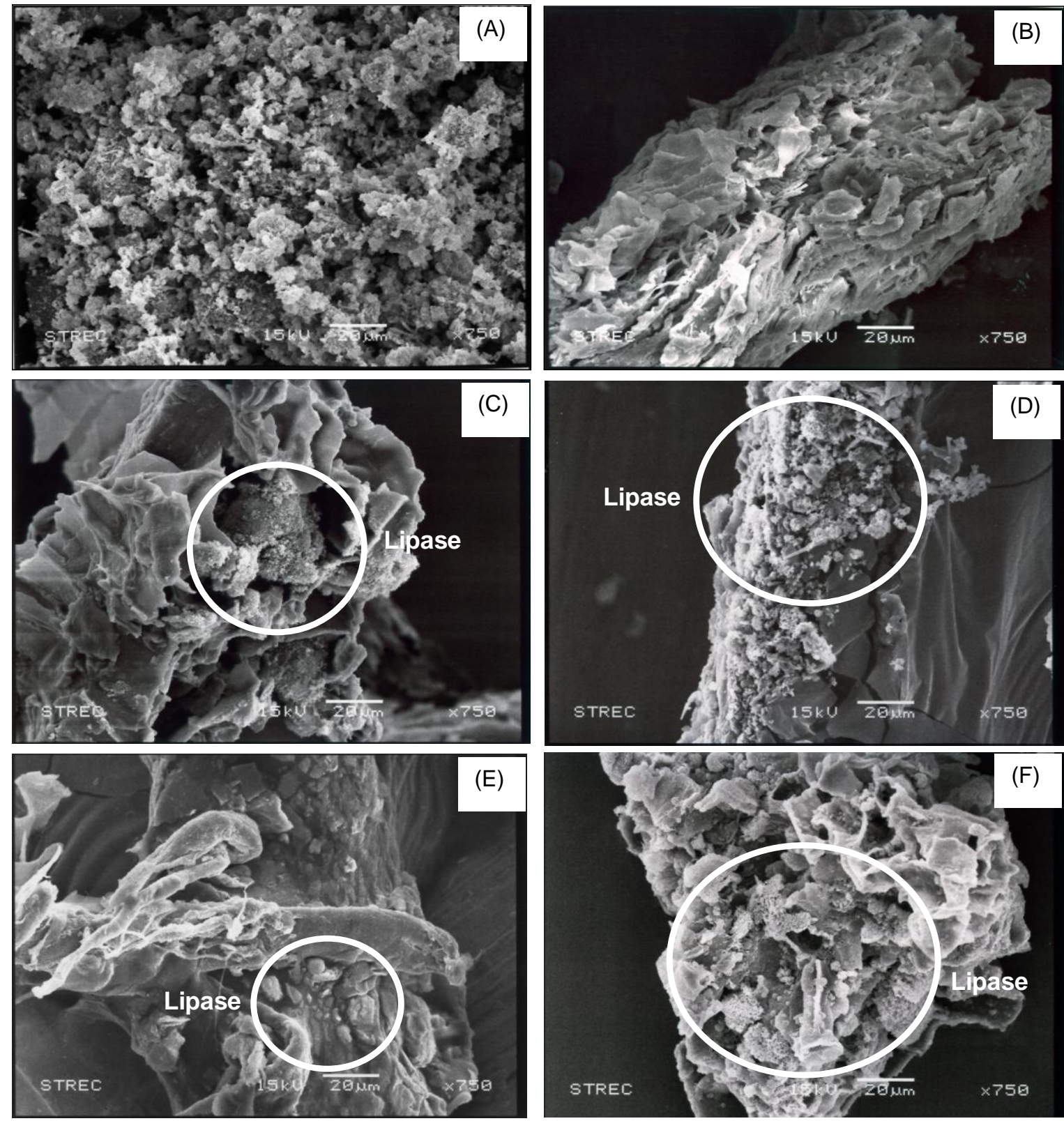

Figure 2. Representative SEM images of the (A) free lipase, (B) fine ground powder of $S$. grossus L.f. fibers, (C-F) immobilized lipase on the $S$. grossus L.f. fibers after activation with 3-APTES $(C, D)$ in distilled water or $(E, F)$ in acetone and crosslinking with $0.5 \%(\mathrm{w} / \mathrm{v})$ glutaraldehyde either $(\mathrm{C}, \mathrm{E})$ after or $(\mathrm{D}, \mathrm{F})$ simultaneous lipase immobilization.

release of $p$-nitrophenol, was measured with a UV spectrophotometer (ANTHOS Zenyth 200 microplate spectrophotometer). One unit $(U)$ of lipase activity was defined as the amount of enzyme required to hydrolyze $1 \mathrm{nmol} / \mathrm{min}$ of $p$-NPP under the experimental conditions.

\section{Determination of protein loading}

Protein concentration was spectrophotometrically determined with a UV spectrophotometer (ANTHOS Zenyth 200 Microplate
Spectrophotometer) according to the Bradford method using bovine serum albumin (BSA) as the standard (Bradford, 1976). The protein loading level is shown as the amount of lipase incorporated in the fibers as a percentage of the total amount added.

\section{Determination of immobilization efficiency}

The efficiency of each immobilization technique, $\eta$, was estimated by calculating the activity of the lipase solution before $\left(E_{0}\right)$ and after $\left(E_{f}\right)$ immobilization, using Equation 1: 
$\eta=\left(\mathrm{E}_{0} \mathrm{~V}_{0}-\mathrm{E}_{\mathrm{f}} \mathrm{V}_{\mathrm{f}}\right) / \mathrm{E}_{0} \mathrm{~V}_{0} \times 100$

Where, $V_{0}$ is the initial volume of lipase solution $(\mathrm{ml})$ and $V_{f}$ is the total volume of lipase solution after filtration $(\mathrm{ml})$. The activities are given in $\mathrm{U} / \mathrm{ml}$.

\section{Biodiesel synthesis}

In this study, the catalytic activities of the immobilized C. rugosa lipase for the hydrolysis-esterification reaction of palm oil and bioethanol as substrates for FAEE biodiesel synthesis were studied through the monitoring of the free fatty acid (FFA) and FAEE production levels as follows:

\section{Hydrolysis of palm oil}

Palm oil was first hydrolyzed by mixing $3 \mathrm{~g}$ of palm oil and $10 \%$ (of the weight of palm oil) of the immobilized $C$. rugosa lipase suspension or the free $C$. rugosa lipase solution. Then, $300 \mu \mathrm{l}$ of distilled water was added to the mixture and continuously stirred at $600 \mathrm{rpm}$ for $12 \mathrm{~h}$ at $50^{\circ} \mathrm{C}$. From this, $100 \mu \mathrm{l}$ of the hydrolytic product was removed and centrifuged at 13,000 rpm for $30 \mathrm{~min}$. The upper phase was used to quantify the FFA composition using high performance liquid chromatography (HPLC) with a, Shimadzu LC20A series (Japan).

\section{Esterification}

The stepwise ethanolysis of palm oil was conducted using a 1:3 molar ratio of palm oil:bioethanol as this ratio has been reported to be optimal (Shimada et al., 1999). However, the bioethanol was added to the hydrolyzed palm oil in three stages feeding of bioethanol at each of 0,8 and $16 \mathrm{~h}$ into palm oil and stirring at 600 rpm for $24 \mathrm{~h}$ at $50^{\circ} \mathrm{C}$. At completion, $100 \mu \mathrm{l}$ of the product was removed and centrifuged at 13,000 rpm for $30 \mathrm{~min}$. The upper phase was used to quantify the FFA and FAEE composition by HPLC as described earlier.

\section{Evaluation of the reusability of immobilized $C$. rugosa lipase}

After being used as a catalyst for the hydrolysis-esterification, the immobilized C. rugosa lipase was filtered, washed with $20 \mathrm{ml}$ heptane and store in a desiccator for $12 \mathrm{~h}$ prior to reuse for the next batch reaction. The conversion of palm oil / bioethanol to FFA and FAEE at the end of the reaction was evaluated by HPLC as aforementioned. This process was repeated until no significant production of FFA or FAEE could not be detected.

\section{RESULTS AND DISCUSSION}

\section{Morphology of the immobilized C. rugosa lipase on $S$. grossus L.f. fibers}

Representative SEM images of the free lipase, ground $S$. grossus L.f. fibers and the $0.5 \%(\mathrm{w} / \mathrm{v})$ glutaraldehyde crosslinked and immobilized $C$. rugosa lipase on $S$. grossus L.f. fibers prepared by different procedures are shown in Figure 2. The presence of lipase particles was seen on the surface and into the pores of the fiber support prepared by all procedures. The activation of the ground S. grossus L.f. fibers support with 3-APTES solution in water $(\mathrm{H} 1$ and $\mathrm{H} 2)$ rendered a higher level of lipase adsorption onto the surface and into the pores of the fiber support than the 3-APTES activation in acetone (A1 and A2). In addition, the lipase adsorption via the simultaneous immobilization and crosslinking procedure revealed a slightly higher lipase adsorption level than the separate immobilization of the lipase after crosslinking.

This can be attributed to: (i) the use of an aqueous swelling medium that favored the diffusion of the coupling agents (3-APTES) into the pores of the cellulose substrate and consequently increased the available interaction area and (ii) the presence of the $\mathrm{NH}_{2}$ groups in the 3-APTES favored the interaction between the coupling agents and the cellulose substrate (Abdelmouleh et al., 2002).

\section{Degree of immobilization and catalytic efficiency}

The use of four different procedures to prepare immobilized lipase, which are the sequential or simultaneous immobilization and crosslinking in water or acetone ( $\mathrm{H} 1, \mathrm{H} 2, \mathrm{~A} 1$ and $\mathrm{A} 2)$, yielded different final lipase activities, protein loading levels, and degree of immobilization and the catalytic efficiencies (Table 1). The highest lipase activity, protein loading and degree of immobilization of the immobilized lipase was achieved by first activating the $S$. grossus L.f. fibers with 3-APTES (in distilled water) and then immobilization of the lipase after crosslinking with glutaraldehyde (treatment $\mathrm{H} 1$; Table 1). However, with respect to the catalytic efficiency, defined as the ratio between the lipase activity and the protein loading level, this method gave a marginally lower catalytic efficiency than when 3-APTES activated in acetone (A1 in Table 1). The higher the catalytic efficiency, the lower the amount of lipase that has been inactivated by the immobilization (Salis et al., 2008).

A higher catalytic efficiency of the immobilized lipase was observed when it was prepared by immobilization after crosslinking rather than when it was simultaneously immobilized and crosslinked regardless of the APTES treatment was in water or acetone (compare treatments A1 with $\mathrm{A} 2$ and $\mathrm{H} 1$ with $\mathrm{H} 2$; Table 1). This is presumed to be because the unreacted aldehyde groups of glutaraldehyde remain after crosslinking with an amino group of the lipase and so can attach to the other amino groups of the lipase, distorting the conformation and so reduce lipase's activity (Lee et al., 2006). In addition, simultaneous immobilization and crosslinking may lead to encourage binding between glutaradehyde and lipase. This may influence to the active site of enzyme and reduce its catalytic efficiency. From these results, the immobilized $C$. rugosa lipase prepared by first activating the ground S. grossus L.f. fibers with 3-APTES in distilled water and subsequentially immobilizing the $C$. rugosa lipase after crosslinking with glutaraldehyde (treatment 
Table 1. Lipase activity, protein loading, degree of immobilization and catalytic efficiency of the immobilized $C$. rugosa lipase prepared by activation of $S$. grossus L.f. fibers with 3-APTES in either distilled water $(H)$ or acetone $(A)$ and then either sequential (treatments $H 1$ and $\mathrm{A} 1$ ) or simultaneous (treatments $\mathrm{H} 2$ and $\mathrm{A} 2$ ) immobilization after crosslinking with $0.5 \%(\mathrm{w} / \mathrm{v})$ glutaraldehyde.

\begin{tabular}{ccccc}
\hline $\begin{array}{c}\text { Technique of } \\
\text { immobilization }\end{array}$ & $\begin{array}{c}\text { Lipase activity } \\
\text { (U/g-fiber) }\end{array}$ & $\begin{array}{c}\text { Protein loading } \\
(\%)\end{array}$ & $\begin{array}{c}\text { Degree of immobilization } \\
(\%)\end{array}$ & $\begin{array}{c}\text { Catalytic } \\
\text { efficiency }^{\text {a }}\end{array}$ \\
\hline H1 & 3.31 & 79.6 & 84.2 & 0.042 \\
H2 & 2.73 & 70.5 & 69.5 & 0.039 \\
A1 & 3.22 & 74.4 & 81.9 & 0.043 \\
A2 & 3.03 & 78.7 & 77.0 & 0.039 \\
\hline
\end{tabular}

${ }^{a}$ Catalytic efficiency is the ratio of the lipase activity to the protein loading level.

Table 2. Effects of varying the glutaraldehyde concentration on the resulting immobilized lipase activity, protein loading, degree of immobilization and catalytic efficiency of the immobilized $C$. rugosa lipase. The immobilized $C$. rugosa lipase was prepared by activation of S. grossus L.f. fibers with 3-APTES in distilled water and immobilized after glutaraldehyde crosslinking (treatment H1).

\begin{tabular}{ccccc}
\hline $\begin{array}{c}\text { Glutaraldehyde concentrations } \\
{[\%(\mathbf{w} / \mathbf{v})]}\end{array}$ & $\begin{array}{c}\text { Lipase activity } \\
\text { (U/g-fiber) }\end{array}$ & $\begin{array}{c}\text { Protein loading } \\
(\%)\end{array}$ & $\begin{array}{c}\text { Degree of immobilization } \\
(\%)\end{array}$ & $\begin{array}{c}\text { Catalytic } \\
\text { efficiency }^{\mathbf{a}}\end{array}$ \\
\hline 0.2 & 3.01 & 80.4 & 76.6 & 0.037 \\
0.5 & 3.31 & 79.6 & 84.2 & 0.042 \\
0.8 & 2.93 & 77.7 & 74.5 & 0.038 \\
\hline
\end{tabular}

${ }^{a}$ Catalytic efficiency is the ratio of the lipase activity to the protein loading level.

(treatment $\mathrm{H} 1$ ) was further investigated. Under this partially optimized condition, the effects of varying the glutaraldehyde concentrations and $\mathrm{pH}$ on the degree of enzyme immobilization and hydrolysis-esterification catalytic activity in the FAEE biodiesel synthesis from palm oil and bioethanol was evaluated next.

Effects of the glutaraldehyde concentrations on the degree of $C$. rugosa lipase immobilization and hydrolysis-esterification catalytic efficiency

The effects of varying the glutaraldehyde concentrations on the resultant lipase activity, protein loading, degree of immobilization and catalytic efficiency of the immobilized $C$. rugosa lipase were evaluated. Immobilized $C$. rugosa lipase was prepared by activation of $S$. grossus L.f. fibers with 3-APTES in distilled water crosslinking with glutaraldehyde at $0.2,0.5$ or $0.8 \%(\mathrm{w} / \mathrm{v})$ and then the lipase was immobilized (treatment $\mathrm{H} 1$ ).

The highest lipase activity, degree of immobilization and catalytic efficiency were achieved with $0.5 \%(\mathrm{w} / \mathrm{v})$ glutaraldehyde, although a slightly higher protein loading level was obtained with $0.2 \%(\mathrm{w} / \mathrm{v})$ glutaraldehyde (Table 2). Too low a glutaraldehyde concentration did not immobilize the lipase enough to be stably held on the fiber surface. In contrast, too high glutaraldehyde concentration would damage the active sites of the lipase (Wang et al., 2008).
Effects of $\mathrm{pH}$ on the degree of $C$. rugosa lipase immobilization and hydrolysis-esterification catalytic efficiency

The effects of $\mathrm{pH}$ on the resultant lipase activity, protein loading, degree of immobilization and catalytic efficiency of the immobilized $C$. rugosa lipase were shown in Table 3. Immobilized $C$. rugosa lipase was prepared by activation of $S$. grossus L.f. fibers with 3 -APTES in distilled water crosslinking with $0.2 \%(\mathrm{w} / \mathrm{v})$ glutaraldehyde and then the lipase was immobilized (treatment $\mathrm{H} 1$ ) at $\mathrm{pH}$ 5,7 and 9. The highest lipase activity, degree of immobilization were achieved at $\mathrm{pH} 7$, whereas, the catalytic efficiency at $\mathrm{pH} 5$ and 7 were similar. Thus, the $\mathrm{pH}$ optimum for the $C$. rugosa lipase immobilization was $\mathrm{pH} 7$ or mild $\mathrm{pH} 5$ rather than $\mathrm{pH}$ 9. This may be the bond between lipase and the support is unstable in basic reaction media $(\mathrm{pH}>7)$ and stable in acid and neutral media ( $\mathrm{pH} 5$ and 7$)$.

\section{Production of FFAs and FAEE biodiesel from palm oil and bioethanol}

The \% conversion of palm oil to FFA (hydrolysis activity) and subsequently with the bioethanol to FAEE (esterification activity) is summarized in Table 4. The three immobilized $C$. rugosa lipase preparations all yielded a higher FFA and especially and importantly, 
Table 3. Effects of pH on lipase activity, protein loading, degree of immobilization and catalytic efficiency of the immobilized $C$. rugosa lipase. The immobilized $C$. rugosa lipase was prepared by activation of $S$. grossus L.f. fibers with 3-APTES in distilled water and immobilized after crosslinking with $0.2 \%(\mathrm{w} / \mathrm{v})$ glutaraldehyde (treatment $\mathrm{H} 1)$.

\begin{tabular}{ccccc}
\hline pH & Lipase activity (U/g-fiber) & Protein loading (\%) & Degree of immobilization (\%) & Catalytic efficiency $^{\text {a }}$ \\
\hline 5 & 2.77 & 72.7 & 76.6 & 0.038 \\
7 & 3.01 & 80.4 & 84.2 & 0.037 \\
9 & 2.16 & 63.2 & 74.5 & 0.034 \\
\hline
\end{tabular}

${ }^{\mathrm{a}}$ Catalytic efficiency is the ratio of the lipase activity to the protein loading level.

Table 4. Conversion of free fatty acid (FFA) and fatty acid ethyl ester (FAEE; biodiesel) produced by the immobilized $C$. rugosa lipase from a 3:1 molar ratio of palm oil: bioethanol. The immobilized $C$. rugosa lipase was prepared by activation of $S$. grossus L.f. fibers with 3APTES in distilled water and immobilized after glutaraldehyde crosslinking at various concentrations (treatment $\mathrm{H} 1$ ).

\begin{tabular}{ccc}
\hline Immobilized C. rugosa lipase [\% (w/v) glutaraldehyde] & Free fatty acid (FFA) (\%) & Fatty acid ethyl ester (FAEE) (\%) \\
\hline Free lipase & 41.6 & 14.7 \\
0.2 & 52.6 & 49.6 \\
0.5 & 43.9 & 32.2 \\
0.8 & 43.5 & 23.7 \\
\hline
\end{tabular}

FAEE production level than that of the free $C$. rugosa lipase. The immobilized $C$. rugosa lipase could catalyze the hydrolysis and esterification reaction relatively efficiently.

Minovska et al. (2005) reported previously that the free enzyme must be used at three-times higher quantities than the immobilized lipase, whilst the free lipase may lose its enzymatic activity under severe environments and with a lower surface area to catalyze the reaction. Of the immobilized $C$. rugosa lipase preparations tested here, that produced by crosslinking with $0.2 \%(\mathrm{w} / \mathrm{v})$ glutaraldehyde provided the highest levels of FFA and FAEE, and so the highest hydrolysis-esterification catalytic activity. Too high concentrations of glutaraldehyde $[0.8 \%(\mathrm{w} / \mathrm{v})]$ gave lower yields, presumably due to the strong covalent binding of the lipase and glutaraldehyde multiple sites causing the enzyme denaturation and loss of some active sites of the lipase.

\section{Reusability of immobilized enzyme for biodiesel synthesis}

The stability of the immobilized lipase is important for any subsequent biodiesel synthesis. Therefore, the long-term stability of the prepared immobilized lipase after biodiesel synthesis was evaluated. The immobilized lipase activity declined after each use for both the hydrolysis (FFA production; Figure $3 \mathrm{~A}$ ) and esterification (FAEE production; Figure $3 \mathrm{~B}$ ) catalytic activities. However, note that the esterification activity is dependent upon the availability of FFA and so a reduction in the hydrolysis efficiency may be manifest as an apparent but false reduction in the esterification catalytic efficiency when FFA levels are low.

The lipase immobilized with $0.2 \%(\mathrm{w} / \mathrm{v})$ glutaraldehyde exhibited the highest reuse stability with some $50 \%$ residual FFA and FAEE levels after three or one reuse, respectively, and with some hydrolysis-esterification activity remaining at up to six reuses (Figure 3B). In contrast, the lipase immobilized with $0.8 \% \quad(\mathrm{w} / \mathrm{v})$ glutaraldehyde exhibited a loss of lipase activity with four uses.

\section{Conclusions}

Optimal immobilization of the $C$. rugosa lipase on the ground biomass of $S$. grossus L.f. fibers was achieved by prior activation of the fibers with $2 \%(\mathrm{w} / \mathrm{v}) 3$-APTES in distilled water followed by crosslinking with $0.2 \%(\mathrm{w} / \mathrm{v})$ glutaraldehyde prior to immobilization of the C. rugosa lipase. A higher concentrations of glutaraldehyde is less efficient presumably because the unreacted aldehyde groups of glutaraldehyde remain after crosslinking with an amino group of the lipase and so can attach to other amino groups of the lipase, thereby reducing the lipase's activity.

In terms of FAEE biodiesel synthesis, the immobilized C. rugosa lipase-catalyzed hydrolysis-esterification of palm oil and bioethanol yielded a higher release of FFAs and conversion to FAEE than those of the free $C$. rugosa. With the $0.2 \%(\mathrm{w} / \mathrm{v})$ glutaraldehyde immobilized $C$. rugosa lipase also exhibited moderate reuse ability for up to six reuses. 


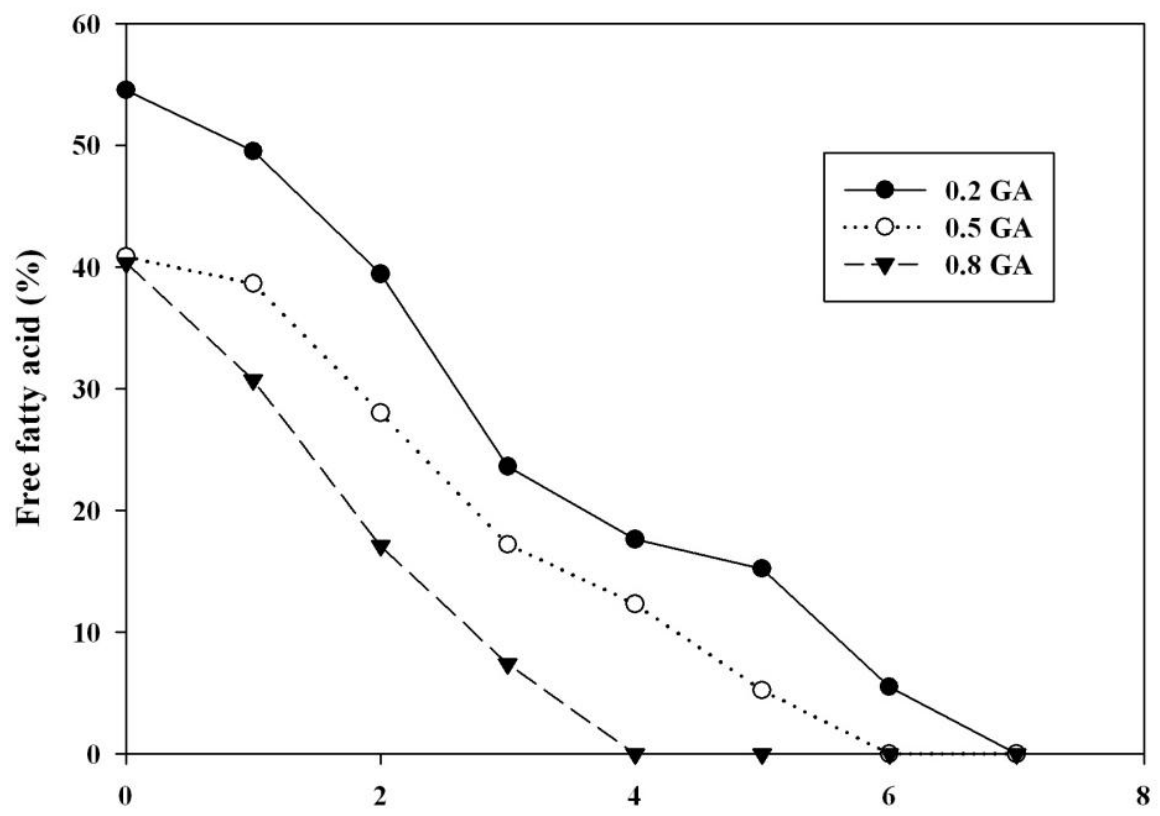

(A) Number of reuse

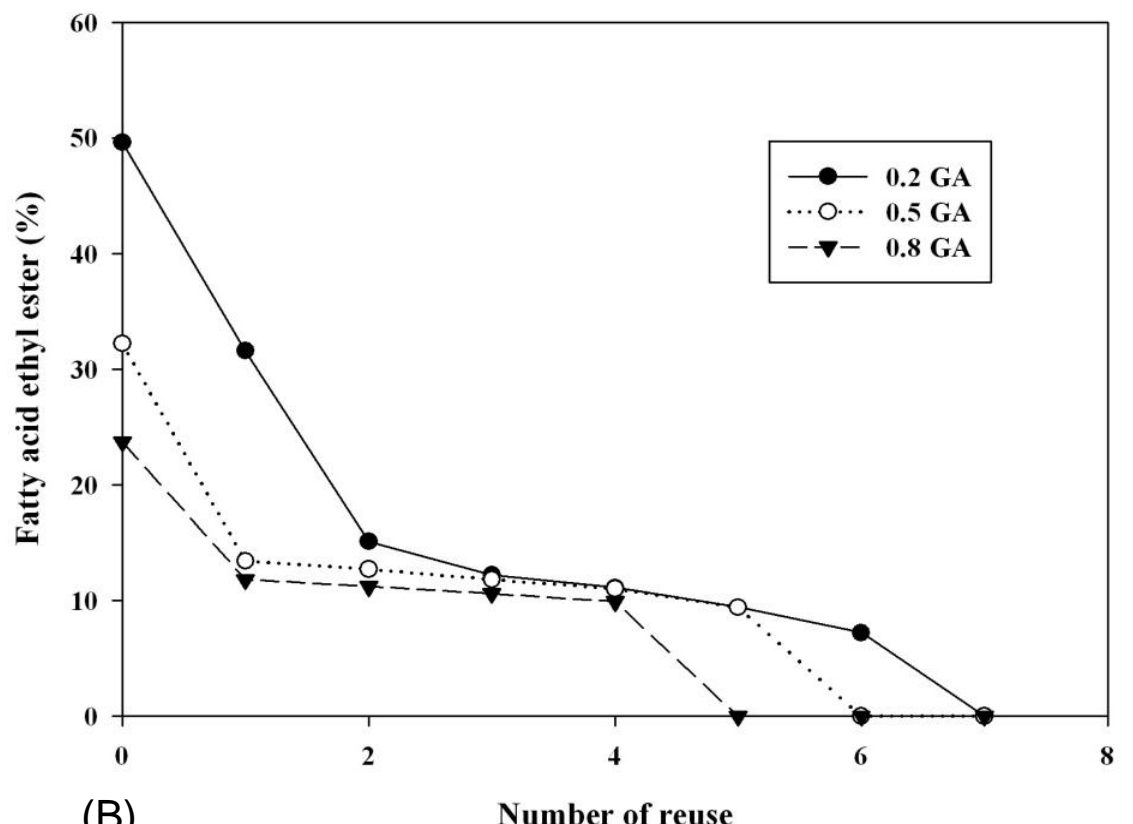

(B)

Number of reuse

Figure 3. The \% production of (A) free fatty acids (FFAs) and (B) fatty acid ethyl esters (FAEE; biodiesel) after repeated use of the immobilized $C$. rugosa lipase on $S$. grossus L.f. fibers crosslinked with various glutaraldehyde (GA) concentrations [as \% (w/v)].

\section{ACKNOWLEDGEMENT}

The authors gratefully acknowledge Dr. Robert Butcher of the Publication Counseling Unit, Research Affairs, Faculty of Science, Chulalongkorn University for his kind language review of this paper.

\section{REFERENCES}

Abdelmouleh M, Boufi S, Salah A, Belgacem MN, Gandini A (2002). Interaction of silane coupling agents with cellulose. Langmuir. 18(8): 3203-3208.

Bradford MM (1976). Rapid and sensitive method for the quantitation of microgram quantities of protein utilizing the principle of protein-dye binding. Anal. Biochem. 72: 248-254. 
Gerpen JV (2005). Biodiesel processing and production. Fuel. Process. Technol. 86: 1097-1107.

Hung TC, Giridhar R, Chiou SH, Wu WT (2003). Binary immobilization of Candida rugosa lipase on chitosan. J. Mol. Catal. B-Enzym. 26:6973.

Lee DH, Park CH, Yeo JM, Kim SW (2006). Lipase immobilization on silica gel using a cross-linking method. J. Ind. Eng. Chem. 12(5): 777782.

Minovska V, Winkelhausen E, Kuzmanova S (2005). Lipase immobilized by different techniques on various support materials applied in oil hydrolysis. J. Serb. Chem. Soc. 70: 609-624.

Nelson LA, Foglia TA, Marmer WN (1996). Lipase-catalysed production of biodiesel, J. Am. Oil. Chem. Soc. 73: 1191-1195.

Przybyt M, Sugier H (1988). Immobilization of glucoamylase on cellulose, Starch - Stärke. 40 (7): 275-279.

Salis A, Pinna M, Monduzzi M, Solinas V (2008). Comparison among immobilised lipases on macroporous polypropylene toward biodiesel synthesis. J. Mol. Catal. B-Enzym. 54: 19-26.

Sugunan S, Gopinath S (2007). Enzymes immobilized on montmorillonite K 10: Effect of adsorption and grafting on the surface properties and the enzyme activity. Appl. Clay. Sci. 35:67-75.
Shimada Y, Watanabe Y, Samukawa T, Sugihara A, Noda H, Fukuda $\mathrm{H}$, Tominaga $Y$ (1999). Conversion of vegetable oil to biodiesel using immobilized Candida antarctica lipase. J. Am. Oil Chem. Soc. 76: 789-793.

Wang Y, Xu J, Luo G, Dai Y (2008). Immobilization of lipase by ultrafiltration and cross-linking onto the polysulfone membrane surface. Bioresource. Technol. 99: 2299-2303.

Xie W, Ma N (2009). Immobilized lipase on $\mathrm{Fe}_{3} \mathrm{O}_{4}$ nanoparticles as biocatalyst for biodiesel production. Energ. Fuel. 23: 1347-1353. 